\title{
EVALUATION OF THE USE OF BIOGAS PLANT DIGESTATE AS A FERTILIZER IN FIELD CULTIVATION PLANTS
}

\author{
Milan KOSZEL, Artur PRZYWARA, Magdalena KACHEL-JAKUBOWSKA, \\ Artur KRASZKIEWICZ \\ Department of Machinery Exploitation and Management of Production Processes, University of Life \\ Sciences in Lublin, POLAND \\ E-mail of corresponding author: milan.koszel@up.lublin.pl
}

Keywords: digestate, fertilizer, winter rape, winter wheat, sustainable agriculture

\begin{abstract}
Biogas production in an agricultural biogas plant is connected with generation of large amounts of postdigestion liquid as a result of anaerobic decomposition of plant debris. Due to its physicochemical properties, post-digestion liquid can be used as a fertilizer. A possibility of agricultural utilization of digestate as a fertilizer was investigated. Digestate obtained from an agricultural biogas plant was tested for the content of macroelements and heavy metals. The content of macroelements was also examined in the soil before and after digestate application. Digestate was used for in the cultivation of fodder winter rape and winter wheat. The content of macroelements as well as the content of protein in the grains of winter wheat fertilized with digestate were on the same levels as in the grains of wheat fertilized with mineral fertilizers. Similar tendency was also observed in winter rape grains. Digestate utilization as a fertilizer brings tangible benefits in agricultural production and can reduce the negative effects of mineral fertilization and contribute to development the sustainable agriculture. The study has shown that digestate can be used as a fertilizer.
\end{abstract}

\section{INTRODUCTION}

Biogas production from anaerobic decomposition has been highly developed in recent years. In this process, large amounts of liquid are also produced. Post-digestion liquid is rich in nitrogen and phosphorus. It is possible to utilize digestate as a fertilizer on farmland (Dębowski et al., 2016).

A biogas plant located in agricultural areas should collect organic products from local farms. Farmers, on the other hand, in their efforts to ensure soil quality on their farms, should use digestate from local biogas plants as a fertilizer (Comparetti et al. 2013, Garfi at al. 2011, Kowalczyk-Juśko et al. 2015, Tao et al. 2014).

Fermented biomass has the same or higher agricultural value than liquid manure since it contains more mineral components (including nitrogen) and less organic matter. Digestate also has undesirable properties, such as: smell, viscosity, considerable humidity and high content of fatty acids which are phytotoxic, this is why digestate can be pathogenic (Bustamante et al., 2014).

The use of post-digestion liquid as a fertilizer brings substantial benefits for agriculture; the possibility of using fermented biomass as a fertilizer contributes to improved soil fertility and higher crop yields. The utilization of post-digestion liquid as a fertilizer leads to the reduction of the use of mineral fertilizers (Cecchi, Cavinato, 2015, Cai et al., 2016, Di Maria et al., 2013).

The aim of this investigation is to examine the justifiability of digestate utilization as a fertilizer in field cultivation of biennial plants, and also compare the content of macroelements after fertilization with digestate and mineral fertilizers in winter rape and winter wheat cultivation. 


\section{METHOD}

Digestate obtained from the biogas plant in Piaski (Lubelskie Province) was applied on experimental fields for winter rape and winter wheat cultivation. There were sown fodder winter rape of Starter variety and wheat of Zyta variety. For the sake of comparison, all the plants mentioned above were sown and fertilized with mineral fertilizers as well. The experimental fields are located in Uchanie Commune, Lubelskie Province. The area of each experimental field was $50 \mathrm{~m}^{2}$. The soil on the fields is 2 nd valuation class. Winter rape was sown at the end of August 2016, winter wheat in the first decade of September 2016. Digestate was used in the amount of 1801 per $50 \mathrm{~m}^{2}(36000 \mathrm{l} / \mathrm{ha})$. On the field fertilized with mineral fertilizers, for winter wheat sowing, there were used: nitrogen $140 \mathrm{~kg} / \mathrm{ha}$ (first dose: pre-sowing and for spring pre-sowing cultivation, second dose in the period of shooting, third dose during earing), phosphorus $-60 \mathrm{~kg} / \mathrm{ha}$, potassium -80 $\mathrm{kg} / \mathrm{ha}$. Rape was fertilized using the following doses: $50 \mathrm{~kg} / \mathrm{ha}$ of Polifoska 6 in autumn, and $65 \mathrm{~kg} / \mathrm{ha}$ of Polifoska 12 in spring.

Digestate was tested for the content of macroelements and heavy metals. Soil samples were examined for the content of macroelements as well. The tests were conducted before and after digestate application.

Laboratory tests were performed at the District Chemical-Agricultural Station in Lublin and in the Central Agro-ecological Laboratory at the University of Life Sciences in Lublin.

\section{RESULTS}

The biogas plant (a biogas combined heat and power plant) is located in Piaski Commune, Lubelskie Province. The electric power is $0,99 \mathrm{MW}$, and the thermal power - 1,1 MW. The annual electricity production - approximately $8400 \mathrm{MWh}$. The generated biogas is desulfurized, dewatered, cooled and pumped by means of an underground gas pipeline into a cogeneration engine which generates electricity and heat in a combined process. The following are used as an input into the digestion process: green waste matter, maize silage, beet pulp, stillage, whey.

Prior to its application, digestate was examined for the content of macroelements and heavy metals (Table 1). The $\mathrm{pH}$ reaction of the digestate used for winter rape and winter wheat cultivation was 8,57 , and it is similar to the $\mathrm{pH}$ reaction of bovine liquid manure $(7,90)$.

The analysis of the results showed that the digestate sample contained no heavy metals. Moreover, the digestate contains substantial amounts of macroelements, therefore it can be used as a fertilizer. This is confirmed by the investigation conducted last year (Koszel et al. 2016).

In view of many authors' indications that digestate does fertilize soil and can be used instead of mineral fertilizers, soil samples were examined as well. Those examinations were also aimed at detecting changes in the content of macroelements. They were performed before and after digestate application. In addition, tests were performed on soil samples after the harvests of winter rape and winter wheat. The results of the analyses are presented in Tables 2 and 3. 

DOI:

Table 1. Comparison of selected macroelements and heavy metals in the digestate used for the field crops

\begin{tabular}{|l|c|}
\hline \multicolumn{1}{|c|}{ Examined feature } & Content in digestate \\
\hline Phosphorus [g/l] & 0,16 \\
\hline Potassium [g/l] & 5,22 \\
\hline Calcium [g/l] & 0,35 \\
\hline Magnesium [g/l] & 0,10 \\
\hline Cadmium [mg/l] & $<0,43$ \\
\hline Lead [mg/l] & $<0,43$ \\
\hline Nickel [mg/l] & $<0,43$ \\
\hline Chromium [mg/l] & $<0,43$ \\
\hline Copper [mg/l] & 0,49 \\
\hline Zink [mg/l] & 2,05 \\
\hline Manganese [mg/l] & 2,00 \\
\hline Iron [mg/l] & 75,66 \\
\hline
\end{tabular}

Table 2. Tests for $\mathrm{pH}$ reaction and macroelements content in the soil for winter rape cultivation

\begin{tabular}{|l|c|c|c|}
\hline \multicolumn{1}{|c|}{ Examined feature } & $\begin{array}{c}\text { Before digestate } \\
\text { application }\end{array}$ & $\begin{array}{c}\text { After digestate } \\
\text { application }\end{array}$ & $\begin{array}{c}\text { After winter rape } \\
\text { harvest }\end{array}$ \\
\hline Reaction [pH] & 7,41 & 7,45 & 7,24 \\
\hline Phosphorus [mg per 100 g of soil] & 41,11 & 50,19 & 47,68 \\
\hline Potassium [mg per 100 g of soil] & 14,30 & 17,73 & 16,79 \\
\hline Magnesium [mg per 100g of soil] & 15,79 & 19,44 & 17,92 \\
\hline
\end{tabular}

Table 3. Tests for $\mathrm{pH}$ reaction and macroelements content in the soil for winter wheat cultivation

\begin{tabular}{|l|c|c|c|}
\hline \multicolumn{1}{|c|}{ Examined feature } & $\begin{array}{c}\text { Before digestate } \\
\text { application }\end{array}$ & $\begin{array}{c}\text { After digestate } \\
\text { application }\end{array}$ & $\begin{array}{c}\text { After winter wheat } \\
\text { harvest }\end{array}$ \\
\hline Reaction [pH] & 7,61 & 7,63 & 7,52 \\
\hline Phosphorus [mg per 100 g of soil] & 50,68 & 59,52 & 56,39 \\
\hline Potassium [mg per 100 g of soil] & 17,12 & 18,63 & 17,70 \\
\hline Magnesium [mg per 100g of soil] & 14,21 & 17,88 & 16,54 \\
\hline
\end{tabular}

The tests of the soil for winter rape cultivation showed a very slight increase in $\mathrm{pH}$ reaction, from 7,41 to 7,45 , then it dropped to 7,24 after the wheat harvest. A similar tendency was observed while testing the soil for winter wheat cultivation. The $\mathrm{pH}$ reaction increased from 7,61 to 7,63, and after the harvest its value dropped to 7,52. The increase in the soil $\mathrm{pH}$ reaction reported above is of no special importance since it is still a basic reaction, which is favourable to good development of plants. After winter wheat harvest the value of $\mathrm{pH}$ reaction was observed to fall to 7,52, which is basic reactions. After the harvest of winter rape $\mathrm{pH}$ reaction value fell to 7,24 , which is a neutral reaction. There was also observed increase in the content of the selected macroelements. 
In winter rape cultivation, after digestate application, the content of phosphorus rose by $9,08 \mathrm{mg}$ per $100 \mathrm{~g}$ of soil, potassium by $3,43 \mathrm{mg}$ per $100 \mathrm{~g}$ of soil, and magnesium by $3,65 \mathrm{mg}$ per $100 \mathrm{~g}$ of soil. As it was in the case of wheat cultivation, also after rape harvest there was observed decrease in the content of macroelements: phosphorus by $2,51 \mathrm{mg}$ per $100 \mathrm{~g}$ of soil, potassium by $0,94 \mathrm{mg}$ per $100 \mathrm{~g}$ of soil and magnesium by $1,52 \mathrm{mg}$ per 100 $\mathrm{g}$ of soil. In winter, wheat cultivation the content of phosphorus rose by $8,84 \mathrm{mg}$ per 100 $\mathrm{g}$ of soil, potassium by 1,51 mg per $100 \mathrm{~g}$ of soil and magnesium by 3,67 mg per $100 \mathrm{~g}$ of soil. Decrease in the content of macroelements was observed after winter wheat harvest: phosphorus by 3,13 mg per $100 \mathrm{~g}$ of soil, potassium by $0,93 \mathrm{mg}$ per $100 \mathrm{~g}$ of soil and magnesium by $1,34 \mathrm{mg}$ per $100 \mathrm{~g}$ of soil. The decrease in macroelement content after the harvests is connected with good absorption of macroelements by plants.

The increase in the content of macroelements in the soil has positive implications. Potassium is a macroelement which has a fundamental significance for plant nutrition. It plays a key role in plant water balance, activates enzymes, takes part in the process of photosynthesis and transportation of assimilates, and also activates sensitivity to water stress associated with drought. The basic role of magnesium in plants is connected with its presence in chlorophyll particles, thus influencing photosynthesis processes. This element plays a significant role in determining the quality of plant products in terms of their nutritional value for animals and people. Phosphorus deficiency inhibits plant growth, reduces yield and its quality. If soil is rich in macroelements, plants absorb them more easily, and produce a higher yield.

Winter rape grains collected from the fields fertilized with mineral fertilizers and digestate were also examined. The mean value of protein content in the winter rape grains collected from the field fertilized with mineral fertilizers was $21,7 \%$, and the mean fat content $-43,4 \%$. In the rape grains collected from the field fertilized with digestate the protein content reached $21,8 \%$, and the fat content $-44,1 \%$. Table 4 shows changes in the content of macroelements in winter rape grains.

Table 4. The content of selected macroelements in winter rape grains

\begin{tabular}{|l|c|c|c|}
\hline Examined feature & $\begin{array}{c}\text { Winter rape sown on the soil } \\
\text { fertilized with mineral fertilizers }\end{array}$ & $\begin{array}{c}\text { Winter rape sown on the soil } \\
\text { fertilized with digestate }\end{array}$ & Difference \\
\hline Nitrogen [\%] & 3,02 & 3,09 & 0,07 \\
\hline Phosphorus [\%] & 0,62 & 0,65 & 0,03 \\
\hline Potassium [\%] & 0,65 & 0,66 & 0,01 \\
\hline Calcium [\%] & 0,49 & 0,50 & 0,01 \\
\hline Magnesium [\%] & 0,37 & 0,37 & 0,00 \\
\hline
\end{tabular}

The analysis of the test results revealed a slight percentage increase in the content of particular macroelements in winter rape grains. The highest rise was observed in the content of nitrogen, $0,08 \mathrm{p}$. p. The relative percent differences for the examined macroelements were as follows: nitrogen $-2,32 \%$, phosphorus $-4,84 \%$, potassium $1,54 \%$, calcium $-2,04 \%$, magnesium $-0 \%$.

Winter wheat grains were collected from the fields fertilized with mineral fertilizers and digestate. The moisture of the grains collected from the field fertilized with mineral fertilizers was $11,8 \%$, and from the field fertilized with digestate $-12,7 \%$. The elementary feature of wheat grains which determines their value in use is protein content. The protein 
DOI:

content in the winter wheat grains collected from the field fertilized with mineral fertilizers was $9,7 \%$, and from the field fertilized with digestate $10,0 \%$. The relative percent difference for the protein content in the wheat grains is 3,09\%. The changes in the content of macroelements in winter wheat grains are presented in Table 5.

Table 5. The content of selected macroelements in winter wheat grains

\begin{tabular}{|l|c|c|c|}
\hline Examined feature & $\begin{array}{c}\text { Winter wheat sown on the soil } \\
\text { fertilized with mineral fertilizers }\end{array}$ & $\begin{array}{c}\text { Winter wheat sown on the soil } \\
\text { fertilized with digestate }\end{array}$ & Difference \\
\hline Nitrogen [\%] & 1,56 & 1,77 & 0,21 \\
\hline Phosphorus [\%] & 0,39 & 0,43 & 0,04 \\
\hline Potassium [\%] & 0,47 & 0,51 & 0,04 \\
\hline Calcium [\%] & 0,11 & 0,12 & 0,01 \\
\hline Magnesium [\%] & 0,19 & 0,19 & 0,00 \\
\hline
\end{tabular}

The analysis of the results revealed a slight percentage increase in the content of particular macroelements in winter wheat grains. The highest rise was observed in the content of nitrogen, 0,21 p. p., as well as phosphorus and potassium, 0,04 p. p. The relative percent differences for the examined macroelements were as follows: nitrogen $-13,46 \%$, phosphorus $-10,26 \%$, potassium $-8,51 \%$, calcium $-9,09 \%$, magnesium $-0 \%$.

\section{CONCLUSIONS}

Anaerobic decomposition is a technology which enables the conversion of food industry or municipal waste into renewable energy sources. The process of anaerobic decomposition consists of a number of metabolic reactions performed by a wide range of microorganisms in anaerobic conditions. As a result, biogas and post-digestion matter are formed (Comparetti et al. 2015).

The major factors determining the way of digestate utilization include its quality, local conditions and legal regulations. In Poland the factor which determines the utilization of biogas plant's by-products is legal norms, which do not facilitate digestate management (Czekała et al. 2012).

This investigation revealed that post-digestion liquid contains large amounts of macroelements. However, no heavy metals were found in digestate. The examination of soil samples before and after digestate application showed increase in the content of macroelements in the soil, which implies a good fertilizing value of digestate.

The examination of winter wheat grains from the soil fertilized with digestate also revealed a rise in protein content as compared to the winter wheat grains from the field fertilized with mineral fertilizers. The investigation results related to winter rape confirmed the efficiency of post-digestion liquid application as a fertilizer. Consequently, post-fermentation residues from biogas plants can be used as a fertilizer.

Fertilizing fields with digestate brings numerous benefits, e.g. reduction of demand for plant protection products (destruction of weed seeds during fermentation), or destruction of possible pathogens. Digestate utilization as a fertilizer brings tangible benefits in agricultural production, but it is also a product the application of which can reduce the negative effects of mineral fertilization and contribute to development the sustainable agriculture. 


\section{REFERENCES}

Bustamante M. A., Moral R., Bonmatí A., Palatsí J., Solé-Mauri F., Bernal M. P., 2014. Intergated Waste Management Combining Anaerobic and Aerobic Treatment: A Case Study. Waste Biomass Valor. 5, 481 - 490. DOI 10.1007/s12649-013-9260-9

Cai J., He P., Wang Y., Shao L., Lü F., 2016. Effects and optimization of the use of biochar in anaerobic digestation of food wastes. Waste Management \& Research. Vol. 34 (5), 409 - 416. DOI $10.1177 / 0734242 \times 16634196$

Cecchi F., Cavinato C., 2015. Anaerobic digestion of bio-waste: A mini-review focusing on territorial and environmental aspects. Waste Management \& Research. Vol. 33 (5), 429 - 438. DOI $10.1177 / 0734242 \mathrm{X} 14568610$

Comparetti A., Febo P., Greco C., Orlando S., 2013. Current state and future of biogas and digestate production. Bulgarian Journal of Agricultural Science. 19 (No 1), 1 - 14.

Comparetti A., Febo P., Greco C., Orlando S., 2015. Italian potential biogas and biomethane production from OFMSW. Ragusa SHWA 2015, IV International Conference on Safety, Health and Welfare in Agriculture Agro-food and Forestry Systems - September 2-5, 2015 HyblaCampus, Ragusta, Sicily - Italy, $1-9$.

Czekała W., Pilarski K., Dach J., Janczak D., Szymańska M., 2012. Analiza możliwości zagospodarowania pofermentu z biogazowni. Technika Rolnicza Ogrodnicza Leśna. 4, 13 - 15.

Dębowski M., Szwaja S., Zieliński M., Kisielewska M., Stańczyk-Mazanek E., 2016. The Influence of Anaerobic Digestion Effluents (ADEs) Used as the Nutrient Sources for Chlorella sp. Cultivation on Fermentative Biogas Production. Waste Biomass Valor. Vol. 8, Issues 37, 1 - 9. DOI: 10.1007/s12649-0169667-1

Di Maria F., Gigliotti G., Sordi A., Micale C., Zadra C., Massaccesi L., 2013. Hybrid solid anaerobic digestion batch: biomethane production and mass recovery from the organic fraction of solid waste. Waste Management \&Research. Vol. 31 (8), 869 - 873. DOI: 10.1177/0734242X13477902

Garfi M., Gelman P., Comas J., Carrasco W., Ferrer I., 2011. Agricultural reuse of the digestate from lowcost tubular digesters in rural Andean communities. Waste Management., 31, 2584 - 2589.

Koszel M., Kocira A., Lorencowicz E., 2016. The evaluation of the use of biogas plant digestate as a fertilizer in alfalfa and spring wheat cultivation. Fresenius Environmental Bulletin. volume 25, No. 8/2016, $3258-3264$

Kowalczyk-Juśko A., Szymańska M., 2015. Poferment nawozem dla rolnictwa. FnRRPR, Warszawa

Tao X., Shang B., Dong H., Chen Y., Xin H., 2014. Effects of digestate from swine manure digester on in vitro growth of crop fungal pathogenes: A laboratory study. Transaction of the ASABE. Vol. 57(6), 18031810. DOI: 10.1303/issn.2151-0032 